\title{
A Breton Bande dessinée? Graphic Mosaics of Brittany \\ Blin-Rolland, Armelle
}

\section{Nottingham French Studies}

DOI:

https://doi.org/10.3366/nfs.2021.0320

Published: 01/07/2021

Peer reviewed version

Cyswllt i'r cyhoeddiad / Link to publication

Dyfyniad o'r fersiwn a gyhoeddwyd / Citation for published version (APA):

Blin-Rolland, A. (2021). A Breton Bande dessinée? Graphic Mosaics of Brittany. Nottingham French Studies, 60(2), 254-271. https://doi.org/10.3366/nfs.2021.0320

\footnotetext{
Hawliau Cyffredinol / General rights

Copyright and moral rights for the publications made accessible in the public portal are retained by the authors and/or other copyright owners and it is a condition of accessing publications that users recognise and abide by the legal requirements associated with these rights.

- Users may download and print one copy of any publication from the public portal for the purpose of private study or research.

- You may not further distribute the material or use it for any profit-making activity or commercial gain

- You may freely distribute the URL identifying the publication in the public portal ?
}

Take down policy

If you believe that this document breaches copyright please contact us providing details, and we will remove access to the work immediately and investigate your claim. 


\section{A BRETON BANDE DESSINÉE? GRAPHIC MOSAICS OF BRITTANY}

\section{ARMELLE BLIN-ROLLAND}

In 2006, an exhibition entitled 'BDZH' ran from April to August in Rhoazon/Rennes to celebrate the vitality of text-image creation in Brittany. The accompanying pamphlet by Alain Goutal and Nicoby, while humoristic in tone, declared Brittany a major comics hub thanks to 'la profusion actuelle de la création, l'effervescence des ateliers, le dynamisme des nouveaux auteurs'. ${ }^{1}$ The name BDZH, combining BD and BZH, echoes comics fields in other stateless cultures such as BDQ (bande dessinée québécoise) and BDG (banda deseñada galega). Yet while most comics creation in BDQ is in French, and BDG usually refers to works in Galician, most of BDZH is not in Breton. This points to the potential for Brittophone creation in what has long been recognized as a major art form, including beyond the youth market in relation to which the medium still tends to be framed in Breton-language publishing. ${ }^{2}$ It also problematizes the 'Bretonness' of a field whose coherence and specificity in the Franco-Belgian context stems not only from a geographical concentration of artists, but also, in part, from an engagement with Brittany as graphic and narrative matter, in its cultural, social and political dimensions.

Taking as its starting point the 'incroyable enracinement de la BD dans la société bretonne' showcased by the exhibition, this article focuses on French-language works that use the formal resources and status of the medium, in different ways and contexts, to mettre en dessin, cadre and page Brittany's difference within and from France. ${ }^{3}$ As such, it returns to and expands Pascal Ory’s 1987 overview of the relationship between comics and Brittany. ${ }^{4}$ I aim to demonstrate the importance of the comics medium for the investigation of artistic articulations of francophone Brittany, and reciprocally, the contribution that francophone Brittany makes to the diversity of bande dessinée studies. With this dual focus, this article is 
indebted to research from both fields. Heather Williams's work on Breton francophone literature, her formulation of the question of what makes a text 'Breton' when it is in French and her development of a postcolonial and ecocritical framework for the study of francophone Brittany, will be key to exploring what perspectives a different medium brings. ${ }^{5}$ In comics studies, this article echoes in particular Jan Baetens's investigation of national cultures in peripheral situations through a case study of Belgian comics, which raises productive questions about the medium's role in the 'constitution/deconstruction of groups and communities'. ${ }^{6}$

The texts discussed in this exploration of graphic francophone Brittany, from the occupation era to today, vary greatly in terms of format, genre, readership, and their use of the possibilities that comics offer as an art form of hybridity and relationality. In order to think through the redrawing of Brittany in these texts, I will use the concept of the mosaic, which has been productively applied in text-image studies by Laurence Grove. ${ }^{7}$ In this article, the mosaic will refer to the form of the comics medium (a whole composed of heterogeneous fragments) as emergent, its elements assembling, dis- and re-assembling through linear and non-linear connections. Comic art will help us see the mosaic as something other than a 'glued and static configuration' in which 'the individual shards never interpenetrate', as Maeve McCusker argues in the context of francophone postcolonial studies, critiquing its use as an inadequate metaphor for créolité. ${ }^{8}$ This understanding of comics as graphic mosaics will entwine with a mosaic view of Brittany, in relation to hybridity and dynamics of 'totalization and fragmentation' with and beyond France. ${ }^{9}$ My overview of the formation, de- and re-formation, of a Breton bande dessinée will start with the text-image construction of a Bretonness centred on 'Doue ha Breiz' (God and Brittany) in the 1940s and 1970s, before turning to the fragmentation of 'la Bretagne dessinée' in the late 1970s and early 1980s, and ending on contemporary ecological and postcolonial graphics. 


\section{'Doue ha Breiz': O Lo Lê and L'Appel d'O Lo Lê}

Herri and Ronan Caouissin's project of 'propagande culturelle bretonne' in the children's illustrated magazine $O$ Lo Lê (1940-4), later revived by Herri Caouissin under the name L'Appel d'O Lo Lê (1970-4), was published against the backdrop of the second Emsav (Breton movement) and the occupation, during which some Breton nationalists collaborated with the Nazis, seeing an opportunity for a Breton state in a dissolved French Republic and a New Order. While $O$ Lo Lê, unlike the Paris-based illustrated magazine Le Téméraire, did not explicitly endorse a Nazi ideology, the magazine openly supported Pétain and exploited his politics of provincialization. ${ }^{10}$ The combination of text and image, in comics and illustrated novels, was used as an ideological tool thanks to its popularity among, and perceived accessibility for, young readers. In his discussion of children's illustrated magazines, Grove uses the image of the mosaic to analyse how different elements provide variety 'whilst linking together to reinforce the overriding message or stance'. ${ }^{11}$ I will build on this to explore the construction of the Caouissins' view of Bretonness across fragmentary combinations of text and image, in the 1940s series Une grande et belle histoire: celle de notre Bretagne and a 1970 comic on the nineteenth-century poet Auguste Brizeux.

Une grande et belle histoire, with text by Herri Caouissin and image by Etienne Le Rallic, was published in serialized form from the first issue of $O$ Lo Le onwards. ${ }^{12}$ The aim is stated from the outset: 'lorsque vous aurez appris l'histoire de nos ancêtres qui formèrent l'un des peuples les plus braves et les plus glorieux de l'Europe, vous serez fiers d'être Bretons'. ${ }^{13}$ The French language is used, as Yvon Tranvouez observes, 'pour ne pas rester confidentiel', and to reach francophone Breton readers whom a nationalized education system has deprived of their language and history. ${ }^{14}$ The format is halfway between illustration and modern bande dessinée, with the text displayed under the image, as was common in $O$ Lo Lê, but images 
here stretch into larger 'tableaux'. This mode of text-image combination, juxtaposing captions written in a subjective and dialogic tone with tableaux drawn in a detailed and realistic style, offers a formal resource for text-image echoes that reinforce an 'histoiremémoire', to use Pierre Nora's term, whereby history is called upon to create a unified memory and legitimate the nation. ${ }^{15}$

The 'caractère unitaire et linéaire de l'histoire-mémoire' materializes through not only sequential but also translinear word-image series. ${ }^{16}$ In the first four episodes, with their images of triskelia, a monk and a battle, readers are told that Brittany is Celtic, Catholic, and independent but threatened by invaders, a message reiterated across the series. ${ }^{17}$ Images of St Yves, missionaries at prayer or a calvary set against a Christianized landscape support verbal reinforcements of Breton devoutness throughout. Numerous battle scenes show Breton armies fighting the Franks, the English or the French, with the reader often sharing the viewpoint of, and therefore encouraged to identify with, the Bretons. The triskelion has multiple connotations of a genealogy of Celtic glory, adorning King Arthur's throne and warriors' shields. When one such shield lies discarded on a field of corpses after the defeat by France at the Battle of Saint-Aubin-du-Cormier (1488), it is the culmination of a visual series lending increased significance to the sight of a triskelion in defeat. ${ }^{18}$ Post-1532, the continuity of Breton resistance against France is reinforced by three consecutive episodes on the revolt against papier timbré under Louis XIV, the Pontcallec conspiracy under the Regency, and the chouannerie under the First Republic. ${ }^{19}$

This is also the story of Brittany's struggle against France, and its eventual absorption into another 'histoire-mémoire', 'son histoire se [confondant] officiellement avec celle de la France' from $1789 .{ }^{20}$ Brittany becomes a fragment of a whole, its cultural rebirth quashed by the 'gouvernement impérial'. ${ }^{21}$ At the end of this grande et belle histoire, a narrative which, in Nora's words, '[indique], du passé, ce qu'il [faut] retenir pour préparer l'avenir', ${ }^{22}$ it is $O$ 
Lo Lê's young readers who are the heirs to Brittany: 'Vous marcherez sur les pas de vos ancêtres en embrassant le noble idéal d'un cœur vaillant breton: Doue ha Breiz! Dieu et Bretagne!'. This motto is reinforced verbally and visually in a tableau showing three children with their arms outstretched towards a calvary upon which it is engraved, in front of a rising sun. The Caouissins' construction of Bretonness is entwined with Brittany's 'new dawn', an image that finds an ideological resonance with the geopolitical context. ${ }^{23}$

Une grande et belle histoire was published in different formats, its episodes collected and its linearity reinforced in the book versions of 1941 and 1943, then fragmented into vignettes for readers to collect and put back together, thereby co-creating Brittany's history from its glorious origins to its new dawn. Initially, the serialized episodes were read as part of the broader $O$ Lo Lê text-image mosaic, their message reinforced by fictional columns about living for 'Doue ha Breiz'. Scenes and figures portrayed in Une grande et belle histoire reappeared across multiple issues, in short- or long-running comics and in different genres. The narrative of the Breton nation repeats and expands, '[formant] la mémoire' of its growing number of young readers turned propagandistes. ${ }^{24}$

The future that was to follow the 'new dawn' in the sequential history of the Breton nation did not, of course, come to pass, and $O$ Lo Lê stopped publication in 1944. The brothers remained militants for the Breton cause, and mobilized the text-image format again to promote their view of Bretonness. It is Herri Caouissin who revived the magazine in 1970 under the name L'Appel d'O Lo Lê. The context, though profoundly different, is described in similar terms to the 1940s: both eras are 'années cruciales'. ${ }^{25}$ The magazine's content was again dominated by Catholicism, Celticity and Breton history, and its form was similar to the first version, though we see the influence of modern bande dessinée in the more frequent integration of text and image. I focus here on a three-page comic on Auguste Brizeux, with text by Herri Caouissin and image by Rémy Bourlès, drawn in a style that is realist but lighter 
than Le Rallic's. Brizeux, a very successful poet in his day but now largely forgotten, is commonly known as a 'barde', 'le chantre de la Bretagne', to which the title of the comic adds 'de la Bretagne croyante'. ${ }^{26}$ As with other comics biographies of 'great Bretons' published in L'Appel, the specificities of the medium - the hybridity and relationality of a text-image mosaic - are used to interweave a figure from Breton cultural history with the magazine's own construction of Bretonness as encapsulated in 'Doue ha Breiz'.

Non-Brittophone Bretons are still a key target of the magazine, and the French language is here both inclusive and implicitly designated as a 'langue étrangère' through the redrawing of the preface to Brizeux's collection Marie (1831). Yet Breton is not absent, featuring in one récitatif and six of the fourteen balloons: in a hymn, giving the poet strength as his 'foi vacille' in Paris; in Brizeux's song 'Ni zo bepred Bretoned, Bretoned, tud kalet' ('We are the Bretons forever, Bretons, a robust people'); in the poet's declarations of commitment to the Breton language and affinity with nature; and in a proverb displaying Breton wisdom. As such, to draw on Thierry Smolderen's terminology, these irruptions of Breton sonorities in the panels as 'image[s] sonore $[s]$ ' may function as 'labels' of selfrepresentation for Brizeux's character, and their emblematic role turns these utterances into words to be learned and repeated by the young readers. ${ }^{27}$

Brizeux's persona, redrawn here with a firmly hagiographic approach, is interwoven with the relationship between Brittany and Paris which, as Williams has shown, is arguably the 'main source of [his] success' as a poet writing to Paris across Brittany. ${ }^{28}$ Yet Brizeux is mis en page as writing precisely across Paris to Brittany: the first and third panels of the opening strip of the second page are linked by symmetrical copies of Marie, the second of which is being read by Hersart de La Villemarqué ('tout mon pays m'apparaît dans ces pages...!'), and a horizontal line could be drawn across the middle panel showing a Parisian salon in rapture at Brizeux's talent. This panel in turn links to another image of a salon, in the 
middle of the bottom strip, which highlights the superficiality of the Parisians who are still lauding Brizeux's verses while gossiping about his hygiene. The poet, who lives a life of poverty and humility, is not only uninterested in writing to Paris, but also now writes for Brittany as shown in the middle strip of the page, as his 'Ni zo bepred Bretoned' is spread among singers at pardons.

Brizeux's Brittany is redrawn here as authentic, rather than a literary invention, and the clichés that he contributed to crystallizing appear as timeless. ${ }^{29}$ When the dying poet returns to Brittany, it is 'pour en fixer une dernière fois les images': the pure and chaste Marie has barely aged, a vision against the background of a Christianized landscape of churches, trees and fields. The last panel shows Brizeux's tomb around which a group of children have gathered, standing for the young readers who are told that his writings are not 'de curieux monuments du passé, mais bien d'éloquents messages'. Beyond the typical use of comics to promote literature, what is striking here is the use of Brizeux's francophone literary representation of Brittany to promote the relevance of the magazine's own construction of Bretonness through bande dessinée.

That this comic lauds a literary Brittany permeated by nostalgia, in a magazine that is itself framed as having been created from a nostalgic impulse, leads us to the question of which past Brittany was longed for across four years in L'Appel. The revived version of the magazine obsessively returns not only to Brittany's glorious past but also to its own, folding in on itself through republications of its back catalogue and images of the 1940s redrawn as a joyful time for ecstatic propagandistes. Its overall mosaic image is now a fantasized past dislocated from the present, the magazine in a sense a remnant of another era for both the Emsav and bande dessinée, as the next section will show.

\section{Fragmenting 'la Bretagne dessinée'}


Text-image works from the late 1970s and early 1980s showcase the ways in which bande dessinée took part in the 'renaissance bretonne'. ${ }^{30}$ The 1960 s to the early 1980 s were a time of change: political engagement, a cultural revolution and social mobilization were entangled in the re-articulation of Bretonness, while the Emsav, which had shifted from conservatism to the left, made the fight for 'internal decolonization' the cornerstone of its action. This was also a time of change for comic art, of taboo-breaking satire and 'expansion and experimentation'. ${ }^{31}$ A key example of how the re-articulation of Brittany intersects with a renewed understanding of the medium's potential is Bran Ruz(h) by Claude Auclair and Alain Deschamps. This reimagining of the Ker-Is legend is a plea for internal decolonization, first published in (À Suivre), a 'revue adulte' in which bédéistes could 's'exprimer en toute liberté. ${ }^{32}$ While Auclair and Deschamps's engagement with the Breton cause is framed as evidence of bande dessinée's potential for telling complex stories, works by cartoonists in the local press drew on the possibilities it offered for journalism. A notable example is Nono's coverage, in Le Canard de Nantes à Brest, of the mobilization against the French state's plan to build a nuclear power plant in the Plogoff area. Combining facts and testimonies with satire and caricature, Nono's reporting both documents and takes a stand on the affair, in a broader denunciation of France's treatment of Brittany.

Cartoonists and bédéistes thus used text and image to document, and as part of their own engagement with, the Breton political and cultural revival. I want to focus here on works that draw on bande dessinée as a medium of fragmentation, demonstrating a different side of the mosaic, namely its potential to fissure and fracture. This is often directed towards FranceBrittany relations, and Nono in Le Canard again provides us with examples. 'Ferniot Rigolo!!' is a satirical redrawing of the 1979 debate between 'jacobins et régionalistes' on the literary talk-show Apostrophes, with the Republican side represented by Jean Ferniot, author of Vous en avez vraiment assez d'être français?. ${ }^{33}$ Comics composition here becomes 
decomposition, in the sense of a 'phénomène opératoire de la (dé-)construction du sens'. ${ }^{34}$ Stylistic hybridity highlights the absurdity of Ferniot's position, and the aesthetic of a 'cartoonish' bande dessinée tradition contrasts with the more realistic style used for panels in which Robert Lafont, Antoine Sanguinetti and Glenmor take apart his arguments. Ferniot's claim that they '[veulent] tuer la nation française!!' is countered through a juxtaposition with Glenmor's mirror account of a school language policy that 'a voulu tuer en moi ma langue maternelle', in the panel immediately below. The cadrage of the television screen within comics panels enables a re-framing, as a commentator appears next to the television to point out the problems in framing Breton as a language spoken only by intellectuals (undermining its claims to 'authenticity') yet also incapable of producing abstract thought (undermining it by suggesting it is inferior to French). In another one-page bande dessinée by Nono, 'Le grand dérangement... quel bordel!', ${ }^{35}$ a Breton commentator also appears, higlighting the dislocation between presenting the support for minority language rights as an autonomist threat within France and presenting it as a sign of cultural richness when discussing the place of French abroad. A cultural exchange between Ploërmel and St. Martinville, Louisiana provides the context in which to redraw a stereotypical Frenchman's defence of Francophonie as fuelled by colonial ideology and postcolonial anxieties: the Frenchman's beret turns into a pith helmet as his call for the promotion of French in the world turns into a rant about the 'loss' of Africa. That a commentator irrupts into the strip to bring this issue 'home' to the national context links the Frenchman's colonial discourse to the linguistic and cultural practices that led to Breton's status as a minoritized language.

These two examples show how formal resources are mobilized to deconstruct French Republican discourses about Brittany. The use of bande dessinée as a medium of fragmentation is also often directed at the clichés of 'la Bretagne' that, as Catherine Bertho has shown, was invented in the 1830s: a 'folkloric' construction whose promotion, as with 
other stateless cultures, was linked to colonial practices of deculturation. ${ }^{36}$ In a context where the poets of decolonization had been revolutionizing the literary representation of Brittany, the text-image medium enables artists to critique clichés such as spirituality or closeness to nature, and to fragment and reconstruct 'la Bretagne dessinée', as evocatively shown in the 1981 collective publication La Jeune B.D. bretonne. ${ }^{37}$

This volume, which gathers established and emerging comics artists' responses to the set theme of 'le problème breton', aims to promote the 'potentiel de création' (p. 39) and comics culture that is starting to take form. The set theme gives the publication a clear 'Breton angle': this is bande dessinée in and about Brittany, whereas the magazine Frilouz (1982-4), which laid the foundations of a network of local artists (including Jean-Claude Fournier, who brought the écolage tradition to Rennes), is more about comics creation in Brittany, though it included some Breton-specific content. This 'jeune B.D. bretonne' is mostly a francophone comic art, though some pieces are wordless, and others feature a small amount of Breton. ${ }^{38}$ The most linguistically inventive is Stéphan's contribution, in which half of the text is in Breton, and half in a French whose syntax clearly denotes that it is a Breton language: 'sell 'ta! s'assombrir le ciel fait?' (La Jeune B.D. bretonne, p. 35).

The image of the mosaic is apt for a collective publication that provides an overall picture of an emerging but already highly varied comics culture. Bédéistes' reponses to 'le problème breton' differ greatly in terms of aesthetics and tone, with sombre, light-hearted, humorous and poetic takes on the issue. What emerges from this hybridity is not only the vibrancy and effervescence of 'l'explosion de la BD en Bretagne' (La Jeune B.D. bretonne, p. 39) but also the complexity of a 'problème breton' that is cultural, economic, social, political and environmental, and often drawn as more of a 'problème français en Bretagne', to use Michel Nicolas's phrasing. ${ }^{39}$ What also emerges is the sense of bédéistes confronting clichés of the 'Bretagne' myth, and de- and re-composing 'la Bretagne dessinée'. This is 
neither Bécassine's backwards and harmlessly different Brittany, nor the Caouissins' eternally glorious one. This Brittany is crushed not only by environmental disasters, mistreatment and repression from the French state, but also by the burden of religion: in his contribution, Yffig draws a man in a traditional Breton costume carrying a cross with a fat bishop sitting on top (La Jeune B.D. bretonne, p. 11).

Ar Roué's two-page bande dessinée 'Men' (La Jeune B.D. bretonne, pp. 4-5) provides a striking opening to the volume. The first four panels feature a sole megalith in the centre, with the sun behind it forming a diagonal path from one image to the next. To a clear sense of temporal progression, the horizontally elongated shape of the panels adds a sense of time stretching into eternity. This regular beat is disrupted in the fifth panel, which contracts in width and expands in height; framing narrows in on the rock around which the ground is fracturing. On the second page, it is the second panel that dominates, showing an excavator digging with its powerful light aimed at the rock, now small and exposed, first unstable and then breaking into pieces in the smaller panels above and below. The layout itself fragments on the vertical axis of the page, with a panel splitting into two smaller ones below, ${ }^{40}$ as the excavator leaves tyre tracks in a landscape that first appeared eternal and is now transformed. Whether this 'jeune BD bretonne' redraws its titular rock being fragmented as a symbol or as a cliché, of a Brittany that is being dismantled or being reinvented, or both, remains up to the reader.

In the pages that follow, the new 'Bretagne dessinée' is a land of emigration, unemployment and social mobilization; its picturesque nature is polluted and radioactive, its coast covered in oil and its 'authentic' culture a marketized folklore. André Morvan draws Bécassine standing in front of a sinking oil tanker as part of a tourist trap vaunting Brittany's 'sites merveilleux et son folklore pittoresque' (La Jeune B.D. bretonne, p. 27). D. Le Page's contribution is a Game of the Goose, where readers can embark on 'tout un périple breton'; 
the board is a spiral of typical images (dolmen, jabadao, calvaries) that also include 'marée noire', 'remembrement', 'chômage' and 'radioactivité' (p. 37). Yves Coriou offers a page where panels come together not in a sequential narrative progression, but by juxtaposing multiple symbolic images of Brittany for the contemporary era, with the stripes of the Breton flag bleeding into prison bars and the nation's map forming a skull (p. 10). It is also the cliché of a feminized Brittany - such as Brizeux's Marie or the mouthless, stupid but loyal Bécassine - that is redrawn. In Nicol and Gueguen's contribution (p. 30), the bigoudène is almost extinct; two men are on the search for the last one, only to find her with her coiffe still upright, a corpse by a derelict traditional Breton house. By contrast, as reimagined by Stéphan, she is Superbigou, flying with a shield on her chest like Superman, vanquishing the vile Parigofric in his Eiffel Tower-shaped spaceship (p. 35).

The 'answer' to the 'problème breton' may be a superhero or, more realistically, Dominig Mevel's call for all Bretons to unite and fight (pp. 24-5). ${ }^{41}$ What is clear is that, across La Jeune B.D. bretonne, the overall mosaic that forms through the cracks is a Brittany that can no longer be thought of unproblematically as an idyllic rural retreat nor as an embalmed ancient culture. In Blut's piece (pp. 8-9), as a reporter investigates what Brittany means to people at L'Ankoo's cabaret, 'la Bretagne' becomes a question repeated over and over, as question marks multiply across the double page. As 'la Bretagne dessinée' fragments, the question becomes: what graphic mosaics of Brittany will (re-)assemble in its wake?

\section{Twenty-first-century ecological and postcolonial graphics}

We now return to the context with which this article opened: the creative potential of the 1980s which led to the vibrant comics scene of today, and to a 'BDZH' positioned as part of a Brittany that has been re-invented in thoroughly progressive terms. ${ }^{42}$ The expansion of 
comics creation in Brittany is clear, but what might the specificities of a Breton field be within the broader contemporary bande dessinée? There are several directions that could be taken here. One is the redrawing of the legendary, as in Annaïg and Loïc Sécheresse's feminist take on Ys (2018), or Nina Luec and Mandragore's Yan'Dargent (2014), a comicspainting dialogue where the fantastic interweaves with Brittany's pictoriality. The redrawing of history is another, one explicitly written out of multiple and contradictory sources, and drawn in fantasy-echoing aesthetics in Thierry Jigourel's series Breizh (2017-present), or Laëtitia Rouxel and Roland Michon's feminist genealogy of Breton women. We could also turn to urban imaginaries: Brest becoming Brest en bulle (as in the name of its comics association), or Laurent Lefeuvre's Rhoazon/Rennes as a city under the protection of superhero Paotr-Louarn/Fox-Boy (2011-present).

Across this diverse and porous field, my analysis echoes directions taken in studies of francophone Breton literature, and focuses on ecological and postcolonial graphics, which were already taking form in the 1970s and early 1980s. ${ }^{43}$ This last section discusses comics that redraw Brittany as a natureculture (to use Donna Haraway's evocative term), and as such make the Breton field a privileged case study for an 'ecographics' ${ }^{44}$ These comics also inscribe the interplay between languages and cultures on and across pages, in an intraHexagonal perspective on what Mary Gallagher calls the 'interval between what we mean by "France" and what we mean by "French". ${ }^{45}$ The mosaic, after giving a shape to conglomeration and fragmentation, shifts into a heterogeneous compound in becoming. Graphic mosaics, as formed of and forming different configurations of elements in interaction, become contact zones (to use the term coined by Mary Louise Pratt in the context of postcolonial literary criticism) between the human and the non-human, nature and culture, languages, identities and cultures. ${ }^{46}$ 
The first graphic narrative through which I explore this is Bruno Le Floc'h's Trois éclats blancs (2004), a fictionalized account of the notoriously difficult construction of the Ar-Men lighthouse (1867-81), here transposed to the early twentieth century. ${ }^{47}$ With its setting 'au bord du monde' (as in the title of Le Floc'h's first publication in 2003), Trois éclats blancs is a graphic exploration of 'blue Brittany'. The sea, by turns calm and troubled, often fills and stretches panels, and the album is notably called 'LA référence' in Emmanuel Lepage's own graphically stunning Ar-Men. ${ }^{48}$ Crucially, however, in Trois éclats blancs this environment of violent marine-human relations is viewed from the perspective of an unnamed Parisian engineer who travels to Brittany to oversee the construction of the lighthouse. His first impressions, as shown in letters displayed as récitatifs, are typical of past French travellers' accounts of their encounter with a country they saw as geographically and temporally distant. From this familiar opening, Trois éclats blancs tells the story of a man who gradually comes to appreciate an environment and a culture that he initially viewed as hostile, and with hostility. The attachment he forms towards 'cette terre et ces gens' (p. 84) makes him want to go further afield: 'ici j'ai pris goût à l'exotisme, à la solitude et à une certaine forme d'exil. Ainsi j'ai postulé pour une mission dans nos colonies' (p. 87).

This text is displayed on an image of the Breton port covered with the French flags that have been multiplying (for the inauguration of the lighthouse) in a translinear series across the comic. The Parisian's perspective is reframed as one that has been seeing Brittany and Bretons through 'imperial eyes' (to use Pratt's expression), and the text/image mosaic shifts into a contact zone that is not, or at least not only, an uplifting narrative of negative 'regional' stereotypes upturned. The opening récitatif talks of the land as an 'étendue nue', seen through eyes that recognize neither the liveliness of the nature nor the rural culture shown in the image (p. 4). A strip in which the Parisian describes the guttural and aggressive sonorities of the Breton language shows Bretons frozen in a stare, their mouths firmly closed, 
the language unheard and expelled to the gutter between the panels (p. 5). Later, when the Parisian is seduced by Perdrix, a young local woman, in their two sex scenes she is drawn as having sexual agency and/or as an exotic fantasy as she takes off her costume (but retains her coiffe), her breasts and buttocks visible while his are covered (pp. 70 and 75). Inhospitable nature is finally conquered with the help of a team of French-speaking natives, and a French flag planted on Ar-Men, held proudly by a boy in a chapeau rond (p. 85).

In the end, the Parisian's transformation remains that of an imperial subject, who sees the colonies as a place for solitude in the wild and self-fulfilment through contact with the 'other'. As such, by taking us to early twentieth-century Brittany through his eyes, Trois éclats blancs arguably opens some of the 'meaning-making powers of the empire' to a revisioning. ${ }^{49}$ It therefore stands in productive contrast to a narrative such as Stéphane Heurteau's 2013 Sant-Fieg. In this fictionalized take on the Front de Libération de la Bretagne (FLB), the 'world's end' is also connected to the French Empire, but the story is set after its collapse overseas and told from the transgenerational perspectives of postcolonial subjects. Tressage effects make an isolated coastal site the emotional and geographical nexus of their family history, and the focus shifts from a centripetal mosaic of Franco-Breton relations to a centrifugal one of 'transcolonial' connections between Brittany and Algeria. ${ }^{50}$ It is worth noting that Heurteau has continued his exploration of colonial conflicts within Europe in his album Long Kesh (2019) about the Irish hunger strike of 1981.

The two graphic narratives I now discuss take us inland, and to relations between languages in translation, and between media in adaptation. These are, respectively, an emergent and an established area in comics studies, but in both fields the context of stateless cultures, so crucial to these texts, remains under-examined. Bertrand Galic and Marc Lizano's Le Cheval d'orgueil is an adaptation of Pierre-Jakez Hélias's self-translation into French (1975) of Breton writings, a text whose portrayal of a 'civilisation morte ou 
agonisante', in Xavier Grall's words, explains both its success in the context of the 'mode rétro' and the controversy it provoked. ${ }^{51}$ The nostalgia of Hélias's book is rendered in the comic through a sepia tone, but the absence of an older narrative voice (or rather its presence only in the epilogue) minimizes the sense of a backward-looking gaze. Lizano's graphics are well-documented and non-realist, positing the adaptation as a re-imagining rather than an ethnographic account. The rural imagery is indeed clearly an imaginary, as a child's perspective dominates, meaning that the environment is also, and prominently so, a playground; there are occasional anthropomorphic graphics, with animals walking on two legs or the grandfather turning into a tree as a materialization of naturalcultural roots (p. 65). Le Cheval d'orgueil relates to what Margaret C. Flinn calls the 'neo-pastoral' in contemporary bandes dessinées about the French terroir but it goes further, pointing towards both the natural and cultural mosaicism of the Hexagon. ${ }^{52}$

While the reader is aware from the start that this is a Brittany in translation, it is with school scenes that the relationship between the language of the characters and that of the comic comes to the fore. Pierre's first day is also his first encounter with the Third Republic's colonial treatment of the Breton language. One strip shows the teacher, her words denoted as French by a cursive typography, scolding the children for speaking Breton as she gradually turns into Marianne against the coloured backgrounds of three panels forming a French tricolore (p. 47). The wordless panel above showing the children chatting shifts into an inscription of the comic's (non-)original language, the silent trace of a 'langue muette', to give a visual dimension to Marc Gontard's literary concept. In a later chapter set at the lycée, both Breton and French are used, in the same standard typography, rendering the fact that the sonorities of French are now familiar to the children. At the top of the page is a sign announcing the infamous injunction 'Il est interdit de parler breton et de cracher par terre!' (p. 123). This juxtaposition is fragmented below through an opposition between Breton 
speakers and French speakers bullying them, as one boy spits on the ground. This panel is divided by the fencepost of the sign, and the interframe space is here not an elliptical blank space, but one already thick with meaning.

These are moments where a relation tending towards destruction is creatively translated into the composite language of comics. As the absence/presence of Breton is (re)inscribed on the page, and French is redrawn, coloured, reframed, this comic complexifies its own 'Frenchness' as a Breton bande dessinée, and a story that is primarily about 'transmission' of natural-cultural roots also points to the fracturing of transmission. ${ }^{53}$ If this may be viewed as a case where the 'translation' has almost fully written out the 'original', it is important to note that it was obvious to the bédéistes that their Cheval d'orgueil had been translated into Breton. ${ }^{54}$

Christelle Le Guen's Anjela, a black and white bilingual graphic narrative about twentieth-century Brittophone peasant-poet Anjela Duval, presents a different configuration of comics-literature, French-Breton and human-nonhuman relations. ${ }^{55}$ Published for the twentieth anniversary of the association Mignoned Anjela, the comic adapts excerpts from her letters and poems into a first-person narrative, and gives an ecological dimension to Hillary Chute's exploration of comic art as a 'poetic endeavor because of how its elements exist in space and meaningfully in relation to each other' ${ }^{56}$ In 'Barzhonegoù-nozBarzhonegoù-deiz'/‘Poèmes de jour, poèmes de nuit' (Anjela, pp. 35-40), where Duval talks of the 'other' poems she writes on and with nature, verses are broken into panels in a textimage mosaic that may assemble also in new directions and through other connections, such as visual lines, rhymes and contrasts. The almost palpable strokes of Le Guen's graphic style render the composite texture of human, animal and vegetal beings, and may be perceived by the reader as the traces left by the gesture of a graphiatrice (to feminize Philippe Marion's 
concept of graphiateur), an abstract echo of the images of Duval's working and writing hands. ${ }^{57}$

It is not only creative but also destructive human-nonhuman relations that are translated into comics form in this ecographic adaptation of ecopoetics. In the last panel of the poem (p. 39), pages are scattered in a wheatfield that fades into a blank space that evokes what these 'vegetal poems' are to become, rather than emptiness.. By contrast, on a double page of 'Paour-kaezh Plouk!'/'Pauvre plouc!' (pp. 25-6), the interplay between black and white is one of erasure: one page whose panels form an image of trees is juxtaposed with another where they are rubbed out, only smudges and edges remaining, in a visual transposition of the destructive practices of land consolidation and intensive farming.

Crucially, Duval's physical and creative engagement with the land is with Brittany, the country on whose flesh (p. 39) and in whose language she writes. One question that the comics discussed so far have raised is: where is the Breton? With Anjela, the question is rather: why is the French there? The French version may introduce non-Brittophones to Duval's poetry, as well as making it more accessible to Brittophones who do not read their language well, which are the reasons why Mignoned Anjela published a bilingual edition of a selection of Duval's poems (Le Guen uses Paol Keineg's translations). ${ }^{58}$ The materiality of this bilingual comic book is also important. The materiality of this bilingual comic book is also important. It is a 'turn-over' format rather than an en-face one, which enables Le Guen to use the full double page. This also has an impact on the dynamics between the two languages, as Breton is not visualized on each page in relation to the language with which it has a history of unequal conflict, and the format may encourage the reader to move away from the 'illusion of one-to-one equivalence' that en-face formats can create through juxtaposition. ${ }^{59}$

It is in the last chapter that de/colonial dynamics come to the fore, closing on a double page of Duval writing a letter in French to the prosecutor in the FLB trial. Duval's words ('la 
Bretagne se meurt', p. 48) weave with spatially distant images of nature dying, as concern for the environment echoes concern for the culture and language with which it is entwined for the peasant-poet. In this story of resistance for 'la Bretagne de demain' (p. 49), a postcolonial perspective entangles with an ecological one across a mosaic of texts, images and languages. This forms a graphic reflection on the "power of culture to (re)shape the word and, through it, the world', to use Graham Huggan's formulation of what postcolonialism and ecocriticism have in common. ${ }^{60}$ This, in a sense, is what the contemporary comics that I have discussed which are all, broadly, about relations - explore creatively and in different ways. Anjela enables us to end this investigation of Breton bande dessinée on a graphic narrative that makes the case not only for a locus of postcolonial and ecological graphics, but also for the potential of a Brittophone comic art.

\section{Conclusion}

My guiding question has been what 'Breton' can mean in relation to French-language comic art. The mosaic, as a shifting shape, has taken us across a history of bande dessinée creation in Brittany, from the text-image construction and promotion of 'Doue ha Breiz', via the fragmentation of 'la Bretagne dessinée', to ecological and postcolonial graphics. This article has shown the productivity of a dialogue between comics studies and studies of francophone Brittany which diversifies our understanding of bande dessinée, and of representations and articulations of Brittany across media. We have seen comics interweave with changing images of Brittany and expressions of Bretonness, including adaptive dialogues with Breton literatures and graphic translations of the absence/presence of languages in contact. Across eight decades, Breton bande dessinée stands as a valuable case study for the aesthetics and politics of children's illustrated magazines; the emergence of a network of artists rethinking and redrawing cultures and identities; and the possibilities that the medium offers for natural- 
cultural imaginaries and internal perspectives on postcolonialism. The analysis has intended not to be exhaustive, but to map out a field, and as such to gesture towards the breadth of the historical, social, political, artistic and environmental graphic narratives of stateless cultures. When we understand comics as a medium of hybridity and relationality that is both accessible and complex, this means that looking back at Breton bande dessinée leads us also to look forward to the Breton francophone, and Brittophone, graphic mosaics yet to come.

\footnotetext{
${ }^{1}$ Alain Goutal and Nicoby, BDZH, l'histoire (Rennes: Les Champs Libres, 2006), p. 30.

${ }^{2}$ On comics in contemporary Breton-language publishing, see my article "“Tu te décolonises": Comics Re-Framings of the FLB (Breton Liberation Front)', Studies in Comics, 10.1 (2019), 73-91 (pp. 80-82).

${ }^{3}$ Ibid., p. 30. 'Mise en dessin', 'cadre' and 'page' are terms developed by Thierry Groensteen in Système de la bande dessinée (Paris: Press universitaires de France, 1999).

${ }^{4}$ Pascal Ory, 'La Bretagne dans la littérature enfantine et la bande dessinée', in Histoire littéraire et culturelle de la Bretagne, tome 3: l'invasion profane, ed. by Jean Balcou (Paris:
} Champion-Slatkine, 1987), pp. 374-81.

${ }^{5}$ Heather Williams, Postcolonial Brittany: Literature between Languages (Oxford: Peter Lang, 2007); 'Pour une éco-poétique de la Bretagne: la nature comme cliché dans les littératures bretonnes', in Regards croisés sur la Bretagne et le Pays de Galles/CrossCultural Essays on Brittany and Wales, ed. by Anne Hellegouarc'h-Bryce and Heather Williams (Brest: CRBC, 2013), pp. 129-44.

${ }^{6}$ Jan Baetens, 'North and South in Belgian Comics', European Comic Art, 1:2 (2008), 11126 (p. 122).

${ }^{7}$ Laurence Grove, Text/Image Mosaics in French Culture: Emblems and Comic Strips (Aldershot: Ashgate, 2005). 
${ }^{8}$ Maeve McCusker, “"This Creole Culture, Miraculously Forged”: The Contradictions of "Créolité", in Francophone Postcolonial Studies: A Critical Introduction, ed. by Charles Forsdick and David Murphy (London: Routledge, 2003), pp. 112-21 (p. 119).

${ }^{9}$ Chris Van Dyke, 'Plastic Eternities and the Mosaic of Landscape', Environment and Planning D: Society and Space, 31 (2013), 400-15 (p. 407).

${ }^{10}$ See Bretagnes et identités régionales pendant la Seconde Guerre mondiale, ed. by Christian Bougeard (Brest: CRBC, 2002) and Pascal Ory, Le Petit Nazi illustré: vie et survie du 'Téméraire' (1943-1944) (Paris: Nautilus, 2002).

${ }^{11}$ Grove, Text/Image Mosaics, p. 87.

${ }^{12}$ Herri Caouissin is also notably the author of the comic Per ar c'holin and co-author (with Léone Calvez) of the play Bécassine vue par les Bretons (1937).

${ }^{13}$ Herri Caouissin and Étienne Le Rallic, Une grande et belle histoire: celle de notre Bretagne, O Lo Lê, 15 November 1940, p. 3. Hereafter UGBH.

${ }^{14}$ Yvon Tranvouez, 'Les Catholiques et la question bretonne (1940-1944)', in Bougeard (ed.), Bretagne et identités régionales pendant la Seconde Guerre Mondiale, pp. 285-306 (p. 295).

${ }^{15}$ Pierre Nora, Les Lieux de mémoire: 1. La République (Paris: Gallimard, 1984), pp. xviixxv.

${ }^{16}$ François Dosse, 'La “Tyrannie” de la mémoire’, Trípodos, 25 (2009), 13-25 (p. 15).

${ }^{17}$ UGBH, O Lo Lê, 15 November 1940, p. 3; 1 December 1940, p. 4.

${ }^{18} \mathrm{UGBH}$, O Lo Lê, 4 May 1941, p. 3.

${ }^{19}$ UGBH, O Lo Lê, 8 June 1941, p. 3; 15 June 1941, p. 3; 22 June 1941, p. 3.

${ }^{20} \mathrm{UGBH}$, O Lo Lê, 3 August 1941, p. 3.

${ }^{21}$ UGBH, O Lo Lê, 17 August 1941, p. 3.

${ }^{22}$ Nora, Les Lieux de mémoire, p. xxiii. 
${ }^{23} U G B H$, O Lo Lê, 28 September 1941, p. 3.

${ }^{24}$ I am borrowing the idea of books forming memory from Nora, Les Lieux de mémoire, $\mathrm{p}$. xxxvi.

${ }^{25}$ L'Appel d'O Lo Lê, 26 (1974), p. 2.

${ }^{26}$ Herri Caouissin and Rémy Bourlès, 'Brizeux, le chantre de la Bretagne croyante', L'Appel d'O Lo Lê, 3 (1970), pp. 2-4.

${ }^{27}$ Thierry Smolderen, Naissances de la bande dessinée: de William Hogarth à Winsor McCay (Brussels: Les Impressions Nouvelles, 2009), pp. 123-4.

${ }^{28}$ Williams, Postcolonial Brittany, pp. 80 and 64.

${ }^{29}$ Ibid., p. 85 .

${ }^{30}$ Nono, Yves Quentel and Daniel Yonnet, Nos années de Breizh (Rennes: Apogée, 1998), p. 87.

${ }^{31}$ Ann Miller, Reading Bande Dessinée: Critical Approaches to French-Language Comic Strip (Bristol: Intellect, 2007), pp. 25-32.

32 Jean-Paul Mougin, 'Éditorial', ('̀ Suivre), 1 (February 1978), p. 3.

${ }^{33}$ Nono, 'Ferniot Rigolo!!', Le Canard de Nantes à Brest, 33 (23 March-6 April 1979), back cover.

${ }^{34}$ Anne Chamayou and Jocelyn Dupont, 'Introduction', in La Décomposition: dynamiques et horizons, ed. by Anne Chamayou and Jocelyn Dupont (Perpignan: Presses universitaires de Perpignan, 2019), pp. 9-12 (p. 10).

${ }^{35}$ Nono, 'Le grand dérangement... quel bordel!!', Le Canard de Nantes à Brest, 35 (20 April-4 May 1979), back cover.

${ }^{36}$ Catherine Bertho, 'L'Invention de la Bretagne: genèse sociale d'un stéréotype', Actes de la recherche en sciences sociales, 35 (1980), 45-62. Williams, Postcolonial Brittany, p. 137. ${ }^{37}$ Collective, La Jeune B.D. bretonne (Saint-Brieuc: Presses Populaires de Bretagne, 1981). 
${ }^{38}$ On Breton-language comics from this era, see Philippe Durand, 'Reconnaissance d'une B.D. bretonne', Pourquoi?, 146 (June 1979), 18-33. Tudu, who was a contributor to Frilouz, is notably the author of Koumanant echu (with Gwendal, 1982) and Kala-mae (with Erwan Kervella, 1987).

${ }^{39}$ Michel Nicolas, Histoire de la revendication bretonne (Spézet/Speied: Coop Breizh, 2007), p. 15.

${ }^{40}$ Renaud Chavanne uses the term 'fragmentation' for panels merging or splitting on the horizontal or vertical axis in Composition de la bande dessinée (Montrouge: PLG, 2010).

${ }^{41}$ This is humorously redrawn as a facial hair issue, which in context can be read as a call for unity also across generations.

${ }^{42}$ Goutal and Nicoby, BDZH, pp. 22-3.

${ }^{43}$ In addition to Williams, see Marc Gontard, La Langue muette: littérature bretonne de langue française (Rennes: Presses universitaires de Rennes, 2008) and Nathalie Caradec, 'La Notion de territoire dans la poésie bretonne de langue française contemporaine', unpublished $\mathrm{PhD}$ thesis (Université de Rennes 2, 2002).

${ }^{44}$ Donna J. Haraway, The Companion Species Manifesto: Dogs, People, and Significant Otherness (Chicago: Prickly Paradigm Press, 2003).

${ }^{45}$ Mary Gallagher, 'Revisiting the "Others' Others”, or the Bankruptcy of Otherness as a Value in Literature in French', Women's Studies Review, 6 (1999), 51-9 (p. 51).

${ }^{46}$ Mary Louise Pratt, Imperial Eyes: Travel Writing and Transculturation, $2^{\text {nd }}$ edn (New York: Routledge, 2008).

${ }^{47}$ Bruno Le Floc'h, Trois éclats blancs (Paris: Delcourt, 2004).

${ }^{48}$ Emmanuel Lepage, Ar-Men, l'enfer des enfers (Paris: Futuropolis, 2017), p. 95.

${ }^{49}$ Pratt, Imperial Eyes, p. 3. 
${ }^{50}$ Françoise Lionnet, 'Transnationalism, Postcolonialism or Transcolonialism? Reflections on Los Angeles, Geography, and the Uses of Theory', Emergences, 10:1 (2000), 25-35.

${ }^{51}$ Bertrand Galic and Marc Lizano, Le Cheval d'orgueil (Paris: Soleil, 2015). Xavier Grall, Le Cheval couché (Paris: Hachette, 1977), p. 88.

${ }^{52}$ Margaret C. Flinn, 'Popular Terroir: Bande Dessinée as Pastoral Ecocriticism?', Studies in $20^{\text {th }} \& 21^{\text {st }}$ Century Literature, 43:1 (2018), 16-21.

${ }^{53}$ Elsa, 'Bertrand Galic et Marc Lizano (Le Cheval d'orgueil), 'interview', 9emeart.fr (2016) $<$ http://www.9emeart.fr/post/interview/franco-belge/bertrand-galic-et-marc-lizano-le-chevald-orgueil-1-interview-5198> [accessed 27 April 2020].

54 'Le Cheval d’orgueil adapté', Le Télégramme (2014),

$<$ https://www.letelegramme.fr/local/finistere-sud/ouest-cornouaille/pontlabbe/bandedessinee-le-cheval-d-orgueil-adapte-15-01-2014-2368812.php> [accessed 27 April 2020]. The translation by Mannaig Thomas was published by Soleil in 2016.

${ }^{55}$ Anjela Duval and Christelle Le Guen, Anjela (Luçon: Pollina/Mignoned Anjela, 2018).

${ }^{56}$ Hillary Chute, 'Secret Labor: Sketching the Connection between Poetry and Comics', Poetry, 202:4 (2013), 379-81 (p. 380).

${ }^{57}$ Philippe Marion, Traces en cases: travail graphique, figuration narrative et participation du lecteur (essai sur la bande dessinée) (Louvain-la-neuve: Academia, 1993).

${ }^{58}$ Quatre poires, <https://www.anjela.org/oberenn/quatre_poires/?lang=en $>$ [accessed 27 April 2020].

${ }^{59}$ Corinna Krause, 'Eadar Dà Chànan: Self-Translation, the Bilingual Edition and Modern Scottish Gaelic Poetry', unpublished PhD thesis (University of Edinburgh, 2007), p. 154. ${ }^{60}$ Graham Huggan, 'Postcolonial Ecocriticism and the Limits of Green Romanticism', Journal of Postcolonial Writing, 45:1 (2009), 3-14 (p. 6). 